\title{
PRODUCTIVITY OF DIFFERENT SPECIES OF DAIRY ANIMALS IN HIGH ALTITUDE REGIONS: A GEOGRAPHICAL ANALYSIS IN PULWAMA DISTRICT OF JAMMU \& KASHMIR
}

\author{
Rafiq Hussain Andrabi* \\ Harmeet Singh \\ and \\ Pervez Ahmed ${ }^{* *}$
}

\begin{abstract}
The study was conducted to assess the existing productivity performance of indigenous and cross-bred cows like Holstein Friesians and Jersey cows in terms of milk yield, age at first calving, post-partum heat, lactation length, dry period, calving interval and lactation yield across different agro-ecological zones (AEZs) of Pulwama district, as these aspects have a profound influence on the efficiency of milk production. For this study, a total of 72 dairy cows were selected randomly from three agro-ecological zones of Pulwama district i.e., Flood Plain, Karewa and Kandi. Significant difference was found within the milk yield $(p<0.01)$, age at first calving $(p<0.01)$, post-partum heat $(p<0.01)$, lactation length $(p<0.01)$, dry period $(p<0.01)$, calving interval $(p<0.01)$ and lactation yield $(p<0.01)$. It was observed that productive and reproductive efficiency of exotic species mainly Jersey and Holstein Friesian remain at the top followed by local/indigenous species. The study concludes that the cross-bred cows are better performers than the indigenous cows in dairy potentialities in the study area. It also reflects that due to robust launching of livestock hybridisation programme in the district, the number of livestock is rapidly being replaced by the cross-breeding animals in order to meet the growing milk demand of the population.
\end{abstract}

\section{Introduction}

The reproductive performance of a herd or an animal is a key indicator of sustainability of a dairy farming system. However, assessment of productive and reproductive performance depends on composite parameters to assess the overall performance evaluation (Islam et al, 2006). The important parameters that determine cattle reproductive and productive efficiency are age at first service, age at first calving, birth weight,

* Doctoral Scholar, Department of Geography, University of Kashmir.

** Senior Assistant Professors, Department of Geography, University of Kashmir. 
total milkyield, average milkyield per day, calving to first service interval and calving interval (Dematawawa and Beger, 1998). They also reported that these parameters are important in terms of economics of dairy management. Similarly,Mukasa-Mugerwa (1989) reported that the most important parameters to measure the farm income are calving interval, age at puberty, service per conception, gestation length and birth weight of fetus. Among these calving interval is considered, probably,the best index of a cattle herd to measure reproductive efficiency. Like other developing countries, India isalso practising improvement of individual cow productivity through crossing the indigenous/ local cattle with breeds like Holstein Friesian and J ersey. However, the performance of the cross-bred cattle varies with different agro-ecological conditions.Milk production in Jammu and Kashmir is also largely affected by a combination of factors, namely, genetic make-up in terms of use of improved breedsselected for milk production, a favourable nutritional environment and improved managerial practices. Consequently, genetic make-up of dairy animals plays a great role in the variation of milk yield and composition. Milk production is, therefore, a factor of genotypeenvironment interactions. It is important to balance selection for both production and functional traits. In Pulwama district the land use trend has changed now. More and more land is being used for production of high value fodder crops, mainly berseem and oats because of robust launching of livestock hybridisation programme in the study area. The number of livestock, being replaced by the cross-breeding animals, is going up rapidly and they need more feed for maintaining their bodygrowth and development. The native cattle of the study area have low productivity but disease resistance capacity is higher than that of exotic breeds. To develop the performance of native cattle, upgradation is necessary. The profitability of dairying depends upon sound management and selection of better genotype which determine the level of production either at farm or at individual level. Most of the cattle population in the district is cross-bred. They are larger in size and their milk production capacity is much larger than that of indigenous breeds. The average milkproduction of a cross-bred cow yield varies between 2500 3000 litres per lactation period of 305 days. The average milk production of a local cow is very low and it varies between 500-1000 litres per lactation period of 305 days. It is interesting to mention here that a reasonable number of landless and marginal farmers have found crossbreeding cows as a profitable enterprise under improved nutrition, better disease control and management. The primary goal of dairy cattle breeding is to increase the efficiency of milk production and the farmers have considered cross-breeding as an alternative to achieve this goal. Conservation and improvement of indigenous animal germplasm are essential for profitable livestock farming to meet the increasing demand of milk. Reproductive efficiency is a major factor in the profitability of a dairy enterprise through its effect on the annual milk production. Thus, a need was felt to understand and document the important parametres pertaining to productive and reproductive performance of dairy breeds. This information could serve as the basis for the exploitation of genetic potential to further the development of dairy industry in the study area and might also be useful for the policy makers in the process of planning and making accurate decisions pertaining to dairy development. 


\section{Study Area}

The study area is centrally located in the Kashmir valley, between $33^{\circ} 37^{\prime}-34^{\circ} 06^{\prime} \mathrm{N}$ latitude and $74^{\circ} 33^{\prime}-75^{\circ} 14^{\prime} \mathrm{E}$ longitude. The district is situated $32 \mathrm{~km}$ from Srinagar in south Kashmir, surrounded by Srinagar in the north, Poonch and
Budgam in the west and Anantnag and Shopian districts in the east and south, respectively. The total geographical area of the district is $787 \mathrm{~km}^{2}$. The study area is mainly divided into three altitudinal zones i.e., Flood Plain which is 1700 metres above the sea level (ASL), Karewa (17002000 metres ASL) and Kandi (2000 metres ASL).

Figure 1: Location Map of Pulwama District

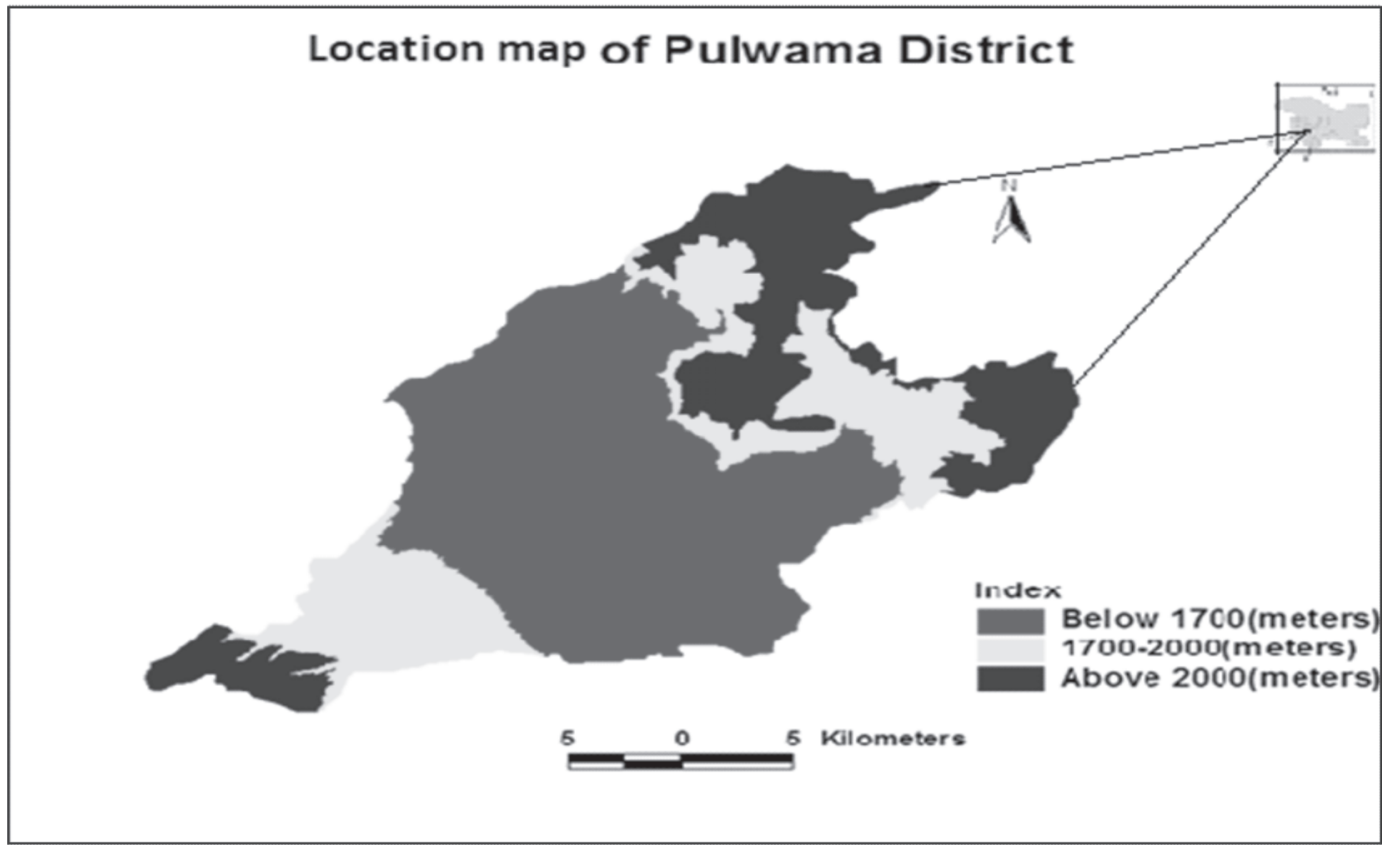

Source: Generated from SOI Toposheets, 1971.

\section{Objectives}

The present study was conducted with the following broad objectives:

1. To study the distribution of livestock in Pulwamadistrict

2. To make a comparative study in the productive performance of different breeds of dairy animals in different regions of the study area.

\section{Methodology}

The present study was carried out by collecting both primary and secondary sources of data. For collecting primary data a structured questionnaire was specifically designed. A total of 72 milch animals from different regions i.e., Flood Plain, Karewa and Kandi of Pulwama district were selected, out of which 22 were Local dairy cows, 23 were Holstein Friesian and the remaining 27 were Jersey. The animals which 
had at least two or three lactation periods were chosen for the study. The data pertaining to indicators of biological efficiency such as age at first calving, lactation period, dry period, calving interval, daily milking average, lactation yield were recorded for all types of animals for comparison. The information on the above mentioned parameters was collected from SheriKashmir University of Agriculture Science and Technology, Kashmir(SKUAST-K). The secondary sources of data were mainly collected from animal and sheep husbandry Department of Pulwama district and Directorate of Statistics and Economics,J \& Kgovernment, in order to know the distribution of dairy animalsin the study area. The collected data was statistically analysed in order to ascertain the statistical difference between the productive and reproductive traits of different species in various biological parameters and this was followed by pair-wise comparisons. The Tukey's test was used for the same in order to ascertain the comparison within the species.

\section{Distribution of Dairy Animals in Pulwama District}

Many factors influence the distribution of dairy cattle in Pulwama district. They include climate, proximity to market and availability of feed and fodder resources. The composition of livestock had changed noticeably during the period. The cross-bred cattle dominated the livestock production system and constituted over 95 per cent of livestock population in the district. Pulwama district is dominated by cattle followed by sheep and goat population. The cross-bred population has increased by 21 per cent but indigenous population has decreased by 15.7 per cent. The animal husbandry in the district has vast scope for exploitation and quick economic returns. On the other hand, population growth, urbanisation and income growth further emphasise the need for improvement of animal husbandry to meet the massive global increase in demand for food of animal origin and animal products.

Table1: Distribution of Dairy Animals in Pulwama District (2014-15)

\begin{tabular}{lcccc}
\hline Tehsils & $\begin{array}{c}\text { Local/Cross } \\
\text { bred Cattle }\end{array}$ & Buffalo & $\begin{array}{c}\text { Species of Dairy Animals } \\
\text { Goat }\end{array}$ & $\begin{array}{c}\text { Total Dairy } \\
\text { Animals }\end{array}$ \\
\hline Pulwama & 54913 & 135 & 3620 & 58668 \\
& $(93.59)$ & $(0.24)$ & $(6.17)$ & $(100)$ \\
Pampore & 13409 & 4 & 591 & 14004 \\
Awantipora & $(95.76)$ & $(0.02)$ & $(4.22)$ & $(100)$ \\
& 17315 & 14 & 709 & 18038 \\
Tral & $(95.99)$ & $(0.08)$ & $(3.93)$ & $(100)$ \\
& 26625 & 769 & 3963 & 31357 \\
Total & $(84.91)$ & $(2.46)$ & $(12.63)$ & $(100)$ \\
& 112262 & 922 & 8883 & 122067 \\
& $(91.96)$ & $(0.76)$ & $(7.28)$ & $(100)$ \\
\hline
\end{tabular}

Source: Animal Husbandry Department, Pulwama, 2015.

Note: Figures in parentheses are percentages.

Journal of Rural Development, Vol. 36, No. 2, April - June : 2017 
Figure2: Distribution of Dairy Animals in Pulwama District (Per cent to total dairy animals)

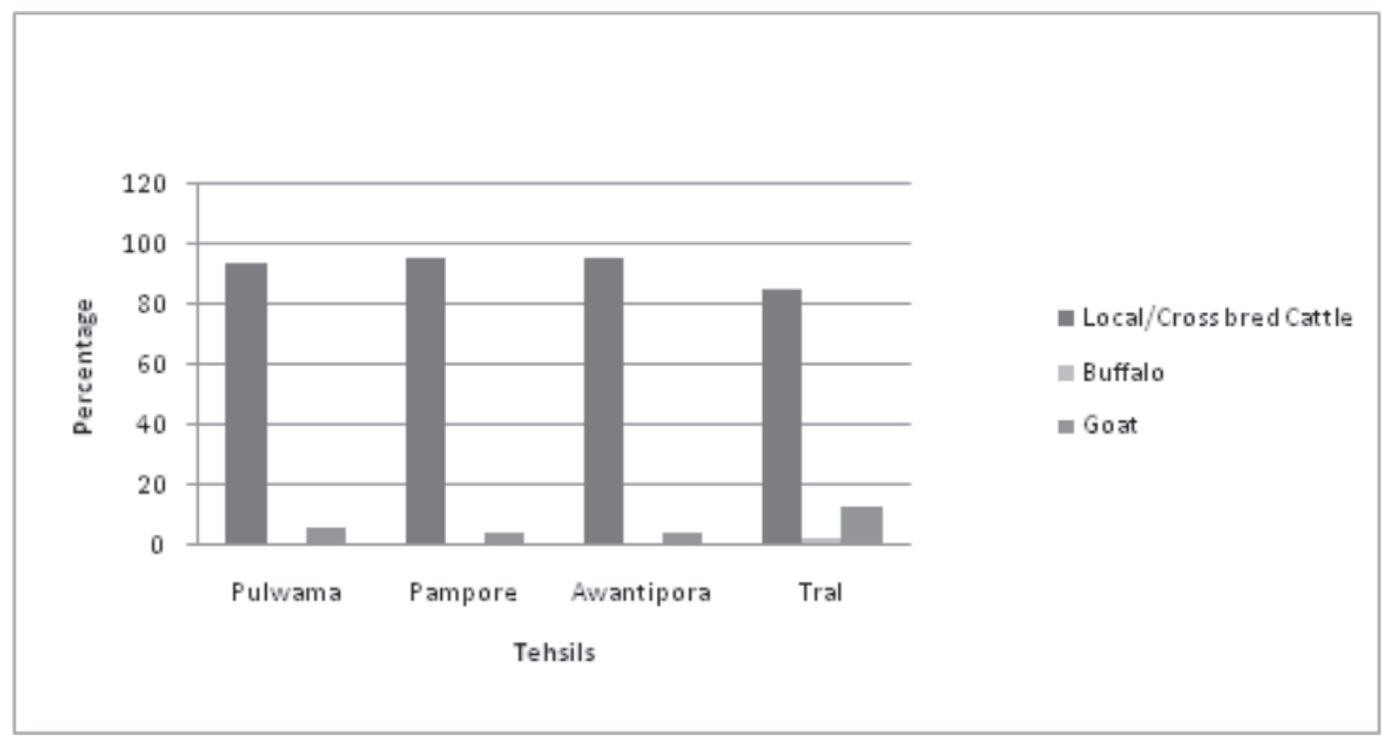

Source: Animal Husbandry Department, Pulwama, 2015.

\section{Production of Milk}

Most of the cattle population in the study area is cross-bred type. They are larger in size and their milkproduction capacity is much higher than that of indigenous breed. Only 0.72 per cent of cattle in the region are local. About 100.02 thousand metric tonnes of milk is produced annually in Pulwama district, out of which 96.21 per cent is contributed by cross-bred animals, 0.72 per cent by local cattle, 0.95 per cent by buffaloes and 2.12 per cent by goats.

Table 2: Breed-wise Distribution of Milk Production in Pulwama District (2015)

\begin{tabular}{lccccc}
\hline Breed & $\begin{array}{c}\text { Cross-bred } \\
\text { Cow }\end{array}$ & Local Cow & Buffalo & Goat & Total \\
\hline $\begin{array}{l}\text { Milk production (000 mts) } \\
\begin{array}{l}\text { Percentage of milk } \\
\text { production }\end{array}\end{array}$ & 100.02 & 0.75 & 0.98 & 2.21 & 103.95 \\
\hline
\end{tabular}

Source: Directorate of Economics and Statistics,J \& K Government, 2015. 
Figure 3: Production of Milk from Different Species of Dairy Animals

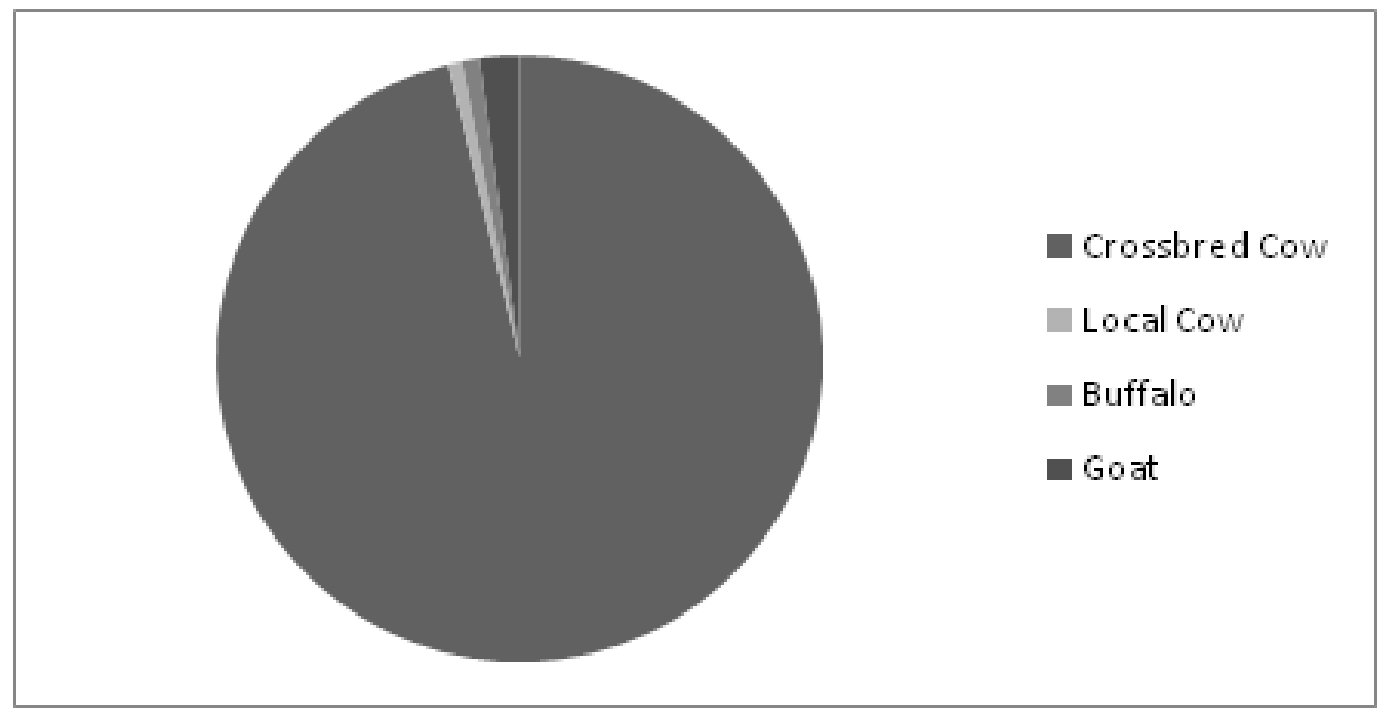

Source: Directorate of Economics and Statistics, J \&K Government, 2015.

\section{Results and Discussion}

A comparison of each parameter revealed a considerable difference between various breeds of dairy animals. The milk yield, age at first calving, lactation length, lactation yield, calving interval, dry period and post-partum heat are the important features associated with dairy animals that are vital for the economic sustainability of a dairy farm. Reduction in the age at first calving and dry period leads to an increase in lactation yield and productive life of the dairy animals and economy of the dairy farm. The information on the reproductive performance of different species of dairy animals is depicted in Table 3.

Table 3: Productivity of Different Species of Diary Animals in Pulwama District

\begin{tabular}{|c|c|c|c|c|c|c|c|c|}
\hline $\begin{array}{l}\text { Agro- } \\
\text { ecolo- } \\
\text { gical } \\
\text { Zone }\end{array}$ & $\begin{array}{c}\text { Specie } \\
\text { of } \\
\text { Dairy } \\
\text { Animal }\end{array}$ & $\begin{array}{c}\text { MilkYield } \\
\text { (Litres/ } \\
\text { Day) } \\
\text { (Mean } \\
\pm \text { SD) }\end{array}$ & $\begin{array}{l}\text { Ageat } \\
\text { First } \\
\text { Calving } \\
\text { (months) } \\
\text { (Mean } \\
\pm \text { SD) }\end{array}$ & $\begin{array}{c}\text { Post- } \\
\text { partum } \\
\text { Heat } \\
\text { (Days) } \\
\text { (Mean } \\
\pm \text { SD) }\end{array}$ & $\begin{array}{c}\text { Lactation } \\
\text { Length } \\
\text { (Days) } \\
\text { (Mean } \\
\pm \text { SD) }\end{array}$ & $\begin{array}{c}\text { Dry } \\
\text { Period } \\
\text { (Days) } \\
\text { (Mean } \\
\pm \text { SD) }\end{array}$ & $\begin{array}{c}\text { Calving } \\
\text { Interval } \\
\text { (Days) } \\
\text { (Mean } \\
\pm \text { SD) }\end{array}$ & $\begin{array}{c}\text { Lactation } \\
\text { Yield } \\
\text { (Litres) } \\
\text { (Mean } \\
\text { 土SD) }\end{array}$ \\
\hline \multirow{5}{*}{$\begin{array}{l}\text { Valley } \\
\text { Floor/ } \\
\text { Flood } \\
\text { Plain }\end{array}$} & cal & $30 \pm$ & $5 \pm$ & 160 & & & \multicolumn{2}{|c|}{$604.65 \pm 1088.69 \pm$} \\
\hline & cow & 82 & 4.7 & 20 & & 28 & & 117.90 \\
\hline & Jersey & $76 \pm$ & $34.58 \pm$ & 11 & & $6 \pm$ & \multicolumn{2}{|c|}{$511.10 \pm 2112.26 \pm$} \\
\hline & & 2.12 & 6.19 & 12.72 & 49.43 & 29.24 & 45.61 & 422.22 \\
\hline & Istein & $9.31 \pm$ & $35.15 \pm$ & $124.05 \pm$ & $321.78 \pm$ & $128.84 \pm$ & \multicolumn{2}{|c|}{$484.89 \pm 3242.42 \pm$} \\
\hline
\end{tabular}

Journal of Rural Development, Vol. 36, No. 2, April - June: 2017 
Table 3 (Contd.....)

\begin{tabular}{|c|c|c|c|c|c|c|c|c|}
\hline $\begin{array}{l}\text { Agro- } \\
\text { ecolo- } \\
\text { gical } \\
\text { Zone }\end{array}$ & $\begin{array}{l}\text { Specie } \\
\text { of } \\
\text { Dairy } \\
\text { Animal }\end{array}$ & $\begin{array}{l}\text { MilkYield } \\
\text { (Litres/ } \\
\text { Day) } \\
\text { (Mean } \\
\pm \text { SD) }\end{array}$ & $\begin{array}{l}\text { Ageat } \\
\text { First } \\
\text { Calving } \\
\text { (months) } \\
\text { (Mean } \\
\pm \text { SD) }\end{array}$ & $\begin{array}{l}\text { Post- } \\
\text { partum } \\
\text { Heat } \\
\text { (Days) } \\
\text { (Mean } \\
\pm \text { SD) }\end{array}$ & $\begin{array}{l}\text { Lactation } \\
\text { Length } \\
\text { (Days) } \\
\text { (Mean } \\
\pm \text { SD) }\end{array}$ & $\begin{array}{l}\text { Dry } \\
\text { Period } \\
\text { (Days) } \\
\text { (Mean } \\
\pm \text { SD) }\end{array}$ & $\begin{array}{c}\text { Calving } \\
\text { Interval } \\
\text { (Days) } \\
\text { (Mean } \\
\pm \text { SD) }\end{array}$ & $\begin{array}{l}\text { Lactation } \\
\text { Yield } \\
\text { (Litres) } \\
\text { (Mean } \\
\pm \text { SD) }\end{array}$ \\
\hline & Friesian & 2.90 & 2.98 & 25.81 & 21.91 & 23.57 & 41.19 & 578.36 \\
\hline & $\begin{array}{c}\text { F-Value } \\
\text { Level of } \\
\text { Significance }\end{array}$ & $\begin{array}{c}44.59 * \\
* * \\
*\end{array}$ & $\begin{array}{c}8.64 * \\
* *\end{array}$ & $\begin{array}{c}12.01 * \\
\text { ** }\end{array}$ & $\begin{array}{c}37.87 * \\
* *\end{array}$ & $\begin{array}{c}42.34 * \\
\text { ** }\end{array}$ & $\begin{array}{c}144.95 * \\
* *\end{array}$ & $\begin{array}{c}44.36 * \\
\text { ** }\end{array}$ \\
\hline \multirow[t]{8}{*}{ Karewa } & Local & $3.21 \pm$ & $41.56 \pm$ & $167.56 \pm$ & $243.47 \pm$ & $176.85 \pm$ & $618.56 \pm$ & $1000.82 \pm$ \\
\hline & cow & 0.73 & 4.48 & 19.72 & 36.97 & 25.95 & 46.63 & 245.89 \\
\hline & Jersey & $5.93 \pm$ & $36.06 \pm$ & $121.00 \pm$ & $293.40 \pm$ & $107.10 \pm$ & $520.43 \pm$ & $2059.90 \pm$ \\
\hline & & 1.63 & 6.33 & 13.85 & 48.05 & 30.52 & 48.04 & 437.49 \\
\hline & Holstein & $8.47 \pm$ & $37.21 \pm$ & $132.05 \pm$ & $313.36 \pm$ & $136.94 \pm$ & $493.05 \pm$ & $3197.05 \pm$ \\
\hline & Friesian & 2.41 & 2.91 & 27.65 & 23.33 & 25.08 & 41.72 & 553.19 \\
\hline & F-Value & $51.34^{*}$ & $8.14 *$ & $18.30 *$ & $41.12^{*}$ & $36.36 *$ & 139.96* & $45.76^{*}$ \\
\hline & $\begin{array}{c}\text { Level of } \\
\text { Significance }\end{array}$ & ** & ** & ** & ** & ** & ** & ** \\
\hline \multirow[t]{8}{*}{ Kandi } & Local & $2.69 \pm$ & $44.47 \pm$ & $160.13 \pm$ & $205.95 \pm$ & $190.30 \pm$ & $633.21 \pm$ & $1088.69 \pm$ \\
\hline & 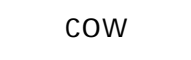 & 0.63 & 4.45 & 20.27 & 39.11 & 28.27 & 51.08 & 20.27 \\
\hline & Jersey & $5.60 \pm$ & $37.96 \pm$ & $115.76 \pm$ & $288.60 \pm$ & $116.10 \pm$ & $558.93 \pm$ & $2065.20 \pm$ \\
\hline & & 1.22 & 6.38 & 17.44 & 104 & 29.96 & 89.09 & 451.65 \\
\hline & Holstein & $6.57 \pm$ & $37.73 \pm$ & $143.94 \pm$ & $295.84 \pm$ & $136.57 \pm$ & $526.78 \pm$ & $2938.57 \pm$ \\
\hline & Friesian & 2.41 & 3.21 & 27.47 & 43.72 & 21.87 & 44.01 & 579.94 \\
\hline & F-Value & $73.29 *$ & 13.06* & $10.22 *$ & $48.60 *$ & $29.33^{*}$ & $101.02 *$ & $13.88^{*}$ \\
\hline & $\begin{array}{c}\text { Level of } \\
\text { Significance }\end{array}$ & ** & ** & ** & ** & $* *$ & ** & ** \\
\hline
\end{tabular}

** Significant at 1 per cent level (0.01). 
Milk Yield: The average daily milk has been considered as an important indicator because it is ultimately milk average that gives a fair return to the farmer. The milk production of indigenous cattle is low as compared to improved breeds. The average milk yield was observed to be $3.30 \pm 0.82$ for Local breed, while for Jersey and Holstein Friesian it was observed to be $6.76 \pm 2.12$ and 9.31 \pm 2.90 , respectively in Flood Plain. The average milk yield in Karewa was 3.21 \pm 0.73 for Local breed and 5.93 $\pm 1.63,8.47 \pm 2.41$ for Jersey and Holstein Friesian. Similarly, in Kandi the average milk yield was observed to be $2.69 \pm 0.63$ for Local breed and 5.60 $\pm 1.22,6.57 \pm 2.41$ for Jersey and Holstein Friesian.

Table 4: Milk Yield Pair-wise Comparison (The figures are in P values)

\begin{tabular}{lccc}
\hline Species of Animal & Local Cows & Jersey & Holstein Friesian \\
\hline Local cows & - & $<0.00$ & $<0.00$ \\
Jersey & $<0.00$ & - & $<0.00$ \\
Holstein Friesian & $<0.00$ & $<0.00$ & - \\
\hline
\end{tabular}

The pair-wise comparison reveals that significant difference $(p<0.01$ ) was found among variousbreedsof dairyanimals.Among the different types of cows, highest milk production was recorded in case of Holstein Friesian and lowest wasrecorded in case of Indigenouscows.

Figure 4: Milk Yield of Different Species of Dairy Animal in Pulwama District

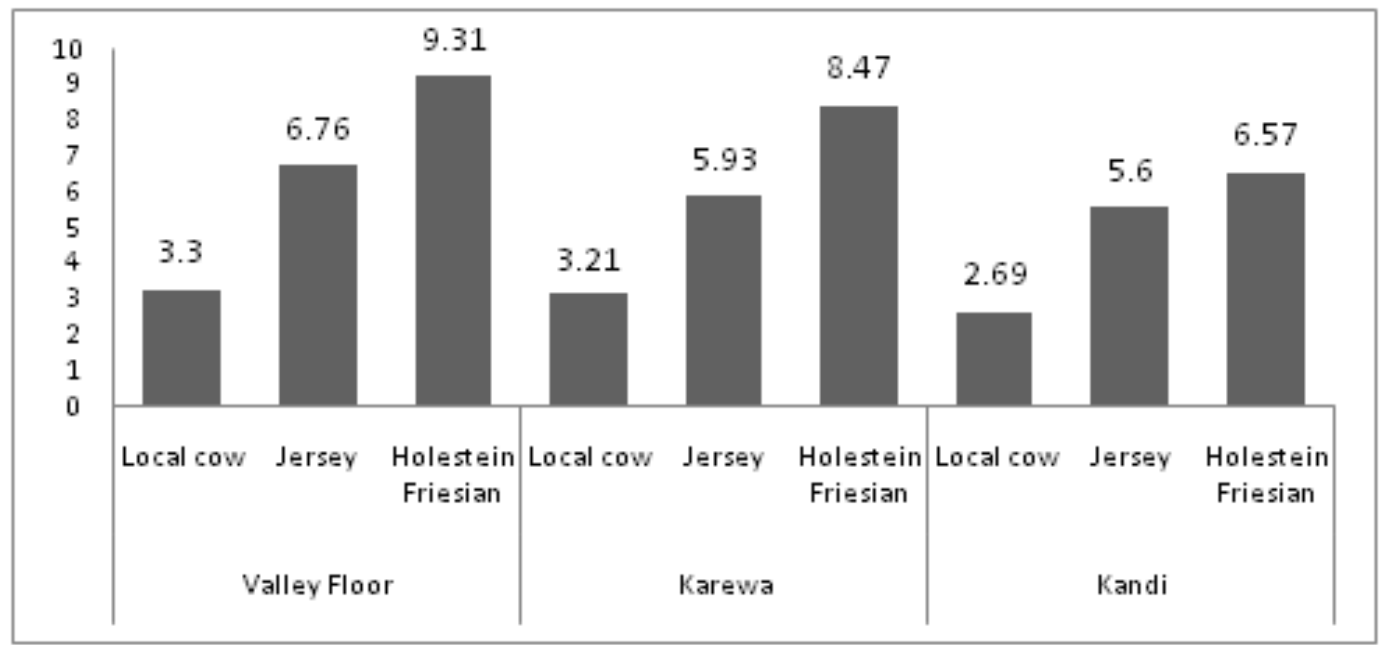

Age at First Calving: Age at first calving was recorded to be $39.95 \pm 4.31,34.58 \pm 6.19$, $35.15 \pm 2.98$ for Local,J ersey and Holstein Friesian, respectively in Flood Plain, while in Karewa the age at first calving was observed to be
$41.56 \pm 4.48,36.06 \pm 6.33,37.21 \pm 2.91$ for Local, Jersey and Holstein Friesian, respectively.Similarly in Kandi, the average age at first calving wasfound to be $44.47 \pm 4.45,37.96 \pm 6.38,37.73 \pm 3.21$ for Local,J ersey and Holstein Friesian, respectively. 
Table 5: Age at First Calving Pair-wise Comparison (The figures are in $\mathbf{P}$ values)

\begin{tabular}{lccc}
\hline Species of Animal & Local Cows & Jersey & Holstein Friesian \\
\hline Local cows & - & $<0.00$ & 0.003 \\
Jersey & $<0.00$ & - & 0.68 \\
Holstein Friesian & 0.003 & 0.68 & - \\
\hline
\end{tabular}

The age at first calving of different genetic groups of dairy animals differed significantly $(p<0.01)$. The highest age at first calving was found among the Indigenous cows and lowest age at first calving was found in Jersey followed by Holstein Friesian cows in different agro-ecological zones of Pulwama district.

Figure 5: Age at First Calving of Different Species of Dairy Animals in Pulwama District

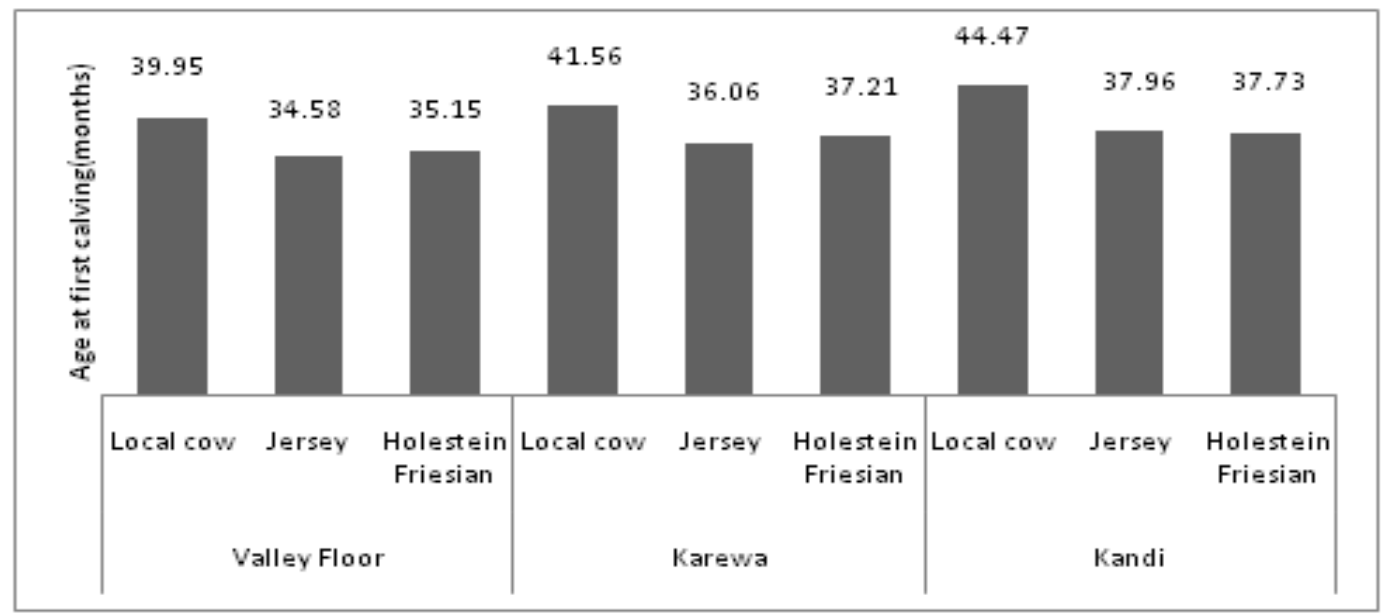

Lactation Yield: The lactation yield wasobserved to be $1088.69 \pm 117.90$ for Local breed, while for J ersey and Holstein Friesian it was observed to be $2112.26 \pm 422.22$ and $3242.42 \pm 578.36$, respectively in Flood Plain. The lactation yield in Karewa was $1000.82 \pm 245.89$ for Local breed and 2059.90 \pm
$437.49,3197.05 \pm 553.19$ for Jersey and Holstein Friesian, respectively. Similarly in Kandi, the average lactation yield was observed to be $1088.69 \pm 20.27$ for Local breed and $2065.20 \pm 451.65,2938.57 \pm$ 579.94 for Jersey and Holstein Friesian, respectively.

Table 6: Lactation Yield Pair-wise Comparison (The figures are in $\mathbf{P}$ values)

\begin{tabular}{lccc}
\hline Species of Animal & Local Cows & Jersey & Holstein Friesian \\
\hline Local cows & - & $<0.00$ & $<0.00$ \\
Jersey & $<0.00$ & - & $<0.00$ \\
Holstein Friesian & $<0.00$ & $<0.00$ & - \\
\hline
\end{tabular}

Journal of Rural Development, Vol. 36, No. 2, April - June : 2017 
The statistical analysisshowed that there was a significant difference among the lactation yield of different types of dairy animals. It was found that the lactation yield of
Holstein was maximum and the lowest lactation yield was found in local cows in different agro-ecological zones of the study area.

Figure 6: Lactation Yield of Different Species of Dairy Animals in Pulwama District

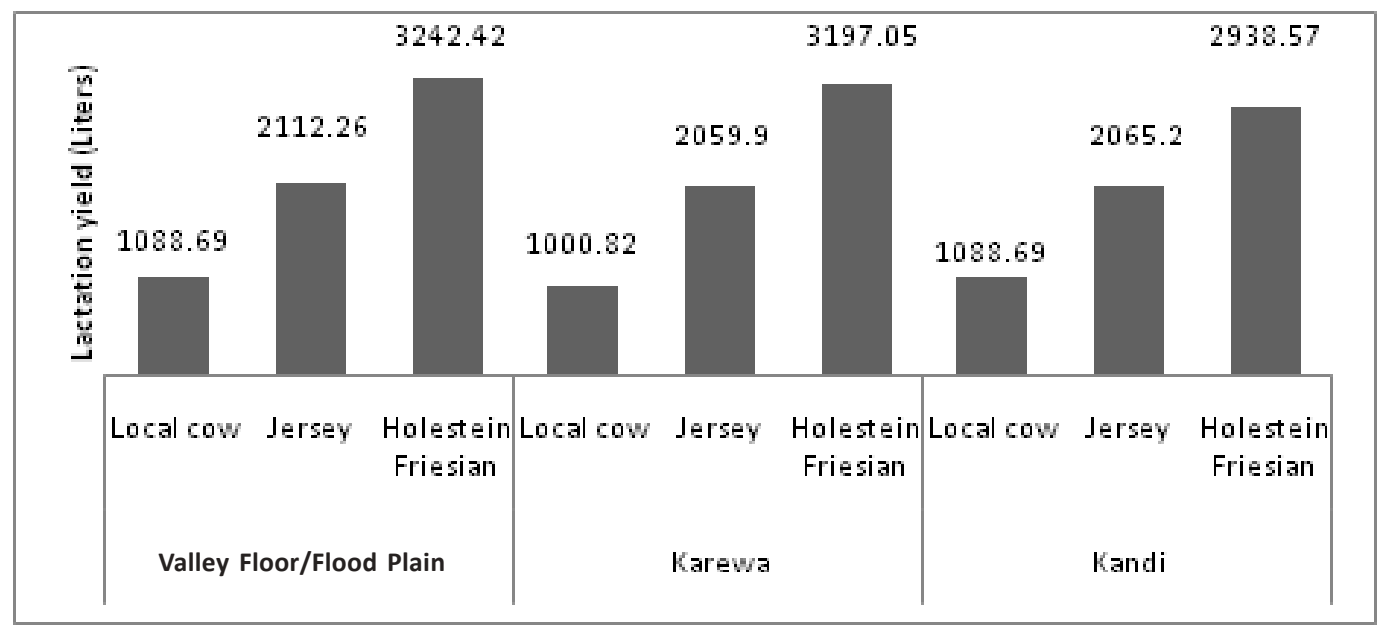

Lactation Length: The lactation length among different breeds of dairy animals was observed to be $263.60 \pm 36.23,301.96 \pm 49.43$, $321.78 \pm 21.91$ for Local, Jersey and Holstein Friesian, respectively in Flood Plain while in Karewa it was found to be $243.47 \pm 36.97$,
$293.40 \pm 48.05,313.36 \pm 23.33$ for Local, Jersey and Holstein Friesian, respectively. Similarly in Kandi region, the lactation length was found to be $205.95 \pm 39.11,288.60 \pm 104,295.84 \pm$ 43.72 for Local, Jersey and Holstein Friesian, respectively.

Table 7: Lactation Length Pair-wise Comparison (The figures are in $\mathbf{P}$ values)

\begin{tabular}{lccc}
\hline Species of Animal & Local Cows & Jersey & Holstein Friesian \\
\hline Local cows & - & 0.001 & $<0.00$ \\
Jersey & 0.001 & - & 0.93 \\
Holstein Friesian & $<0.00$ & 0.93 & -
\end{tabular}

The study reveals that there was statistically significant differenceamong different breeds of cattle in lactation length $(p<0.01)$.The pair-wise comparisons reveal that there was significant difference among Holstein Friesian, Jersey and Local cows. The lactation length was higher in Holstein Frisian cows followed by Jersey and the lowest was found in Local cows.

Dry Period: The dry period was found to be $167.56 \pm 28.57$ for Local while for Jersey and Holstein Friesian it was observed to be $100.86 \pm 29.24$ and $128.84 \pm 23.57$, respectively. 
The dry period in Karewa was found to be $176.85 \pm 25.95,107.10 \pm 30.52,136.94 \pm 25.08$ for Local,J ersey and Holstein Friesian, respectively. Similarly for Kandi, the average dry period was observed to be $190.30 \pm 28.27,116.10 \pm 29.96$, $136.57 \pm 21.87$ for Local, Jersey and Holstein Friesian, respectively.

Table 8: Dry Period Pair-wise Comparison (The figures are in $\mathrm{P}$ values)

\begin{tabular}{lccc}
\hline Species of Animal & Local Cows & Jersey & Holstein Friesian \\
\hline Local cows & - & $<0.00$ & $<0.00$ \\
Jersey & $<0.00$ & - & 0.001 \\
Holstein Friesian & $<0.00$ & 0.001 & - \\
\hline
\end{tabular}

The mean dry period of various species of dairy animals reveals that statistically it differs significantly $(p<0.01)$. Statistical analysis reveals that there was significant difference among Holstein Friesian, Jersey and Local cows. It is observed that highest dry period was found among Local cowsfollowed by Jersey and lowest dry period was observed in Holstein Friesian.

Calving Interval: The calving interval in Flood Plain was found to be $604.65 \pm 45.84$,
$511.10 \pm 45.61,3242.42 \pm 578.36$ for Local, J ersey and Holstein Friesian, respectively. In Karewa region, the calving interval was observed to be $618.56 \pm 46.63$ for Local while for Jersey and Holstein Friesian it was found to be $520.43 \pm 48.04$ and $493.05 \pm 41.72$, respectively. Similarly in Kandi region, the average calving interval was observed to be $633.21 \pm 51.08$. While for Jersey and Holstein Friesian, it was observed to be $558.93 \pm 89.09$ and $526.78 \pm 44.01$, respectively.

Table 9: Calving Interval Pair-wise Comparison (The figures are in $\mathrm{P}$ values)

\begin{tabular}{lccc}
\hline Species of animal & Local Cows & Jersey & Holstein Friesian \\
\hline Local cows & - & $<0.00$ & $<0.00$ \\
Jersey & $<0.00$ & - & 0.33 \\
Holstein Friesian & $<0.00$ & 0.33 & - \\
\hline
\end{tabular}

The mean calving interval of various species of dairy animals reveals that statistically it differssignificantly $(p<0.01)$. Among the different species of dairyanimals, thehighest calving interval wasfound in Local cowsand the lowest in Holstein Friesian followed by Jersey cows.

Post-partum Heat: Thepost-partum heat in Flood Plain was observed to be $160.13 \pm 20.27,111.70$ $\pm 12.72,124.05 \pm 25.81$ for Local, Jersey and Holstein Friesian, respectively. In Karewa, the average post-partum heat was observed to be $167.56 \pm 19.72,111.70 \pm 12.72,124.05 \pm 25.81$ for Local,J ersey and Holstein Friesian, respectively. Similarly in Kandi, the average post-partum heat was found to be $160.13 \pm 20.27,115.76 \pm 17.44$ $143.94 \pm 27.47$ for Local, Jersey and Holstein Friesian, respectively. 
Table 10: Post-partum Heat Pair-wise Comparison (The figures are in $\mathbf{P}$ values)

\begin{tabular}{lccc}
\hline Species of Animal & Local Cows & Jersey & Holstein Friesian \\
\hline Local cows & - & $<0.00$ & $<0.00$ \\
Jersey & $<0.00$ & - & $<0.00$ \\
Holstein Friesian & $<0.00$ & $<0.00$ & -
\end{tabular}

Post-partum heat period was calculated as the interval between parturition to next heat that was observed after a certain period of parturition. Earlier the post-partum period, the shorter will be the calving interval. The length of thepost-partum interval isinfluenced bynutrition, body condition, age, biological efficiency and presence of calf. Post-partum heat of dairy animals shows that it differs significantly $(p<0.01)$. Table 10 reveals significant difference among Local, Holstein Friesian and J ersey cows. It was observed that the shortest post-partum heat period was in J ersey followed by Holstein Friesian and Local cows.

\section{Figure 7: Reproductive Parameters of Different Species of Diary Animals in Pulwama District}

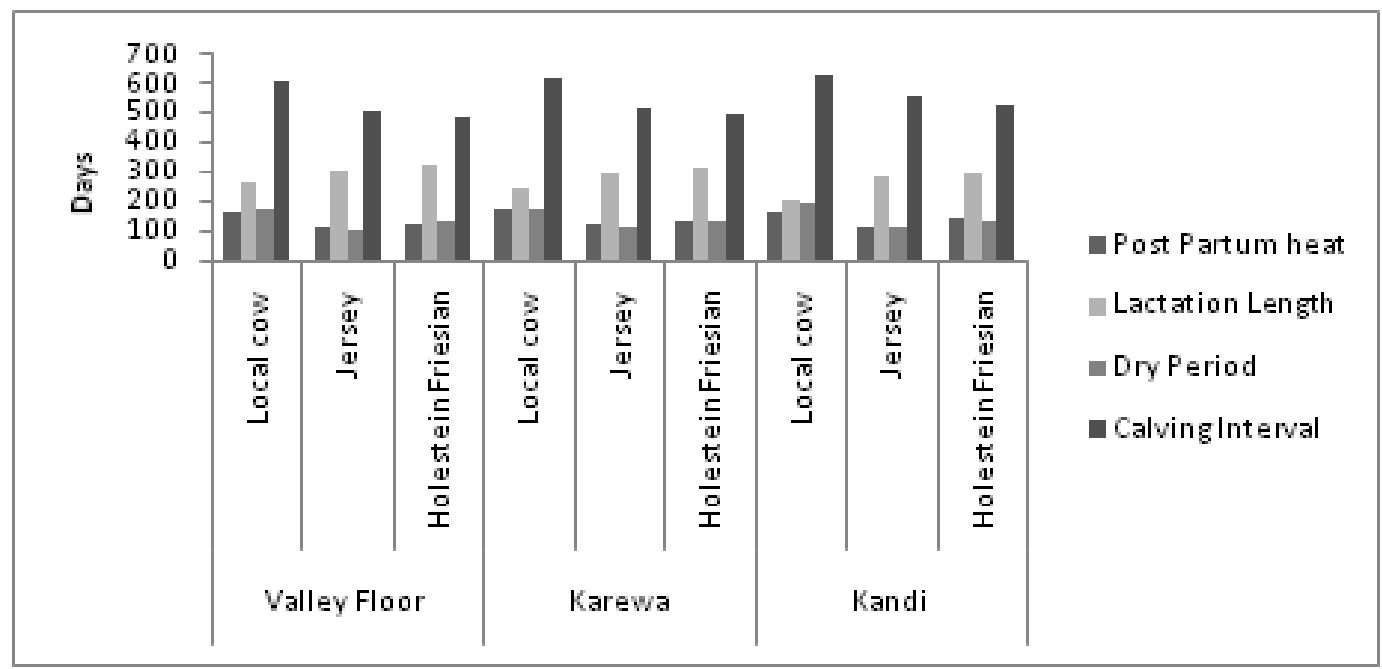

\section{Conclusion}

The study reveals that productive and reproductive performance ishigher in cross-bred cattle than the Indigenous species. It depicts that productive performance of Holstein Friesian and Jersey cows were better than that of Indigenous ones. Although the native Local cows produce little milk than cross-bred cows, they are better adjusted with local climatic conditions. For the improvement of the breed of cows, there is a need to consider the relative efficiency of productive and reproductive performance of different cross-breds existing in our country and then their adaptability to climate. Therefore, a selection programme is to be implemented by considering the breed characteristics of the cows and that will strengthen the breeding policy for different States. 


\section{References}

1. Alam, M.G.S, Ghosh, M and Akbar M.A (2001), "Supplementation and Puberty of Zebu Calves in Bangladesh, The Bangladesh Veterinarian-18, pp.1-8.

2. Andrea, S.W (2004), "An Ecology of High- Altitude Infancy - A Bio Cultural Perspective," Syndicate of the University of Cambridge, pp. 112-118.

3. Bisht, R (2008), "Agriculture in Ladakh: A Status Report," Prepared for TATA-LAHDC-Development Support Programme, Mumbai, pp. 34-36.

4. Dematawewa, C. M. B, and Beger P.J (1998), "Genetic and Phenotypic Parameters for 305-day Yield," Fertility and Survival in Holstein. J, Dairy Science 81,2700-2709.

5. Department of Animal Husbandry (2015), "Annual Report," Department of Animal Husbandry, Pulwama, pp. 1-4.

6. Government of Jammu and Kashmir (2015), "Digest of Statistics," Directorate of Economics and Statistics, Planning and Development Department, pp. 45-55.

7. Ishaq, S.M (1961), "An Economic Analysis of the Influence of Delayed Breeding on Milk Production and Cost in Dhanni Cows,"Agriculture Pakistan 12, pp. 61-66.

8. Islam, S.K.M.A, Zhoque, M.A, Alam, M.R, Hassan, M.M and Rehman, M.A (2006),"A Cross-sectional Study on Production Performance of Stall-fed Dairy Cattle at Central Cattle Breeding Station (CCBS), Savar, Dhaka Bangladesh, J. Vet. 4(1):61-63.

9. Kumaresan, K (2009), "Comparative Study on Productive and Reproductive Performance of Local and Different Cross-bred Dairy Cows at Daulatpur, Khulna in Bangladesh,"Bangladesh Research Publications Journal, Volume- 3, pp.909-914.

10. Miazi,. M,Hossain E., and Hassan, M (2007), "Productive and Reproductive Performance of Crossbred and Indigenous Dairy Cows under Rural Conditions in Comilla, Bangladesh," Univ.j. zool. Rajistani Univer, Vol.26, pp.67-70.

11. Mukasa- Mugerwa, E (1989), “A Review of Reproductive Performance of Female Boslndicus (Zebu) Cattle," Addis Ababa, Ethiopia: International Livestock Centre for Africa. 